\title{
Readiness of Health Workers to Provide Pregnancy Planning Program for Women Infected with Human Immunodeficiency Virus: A Case Study in Surabaya, East Java, Indonesia
}

\author{
Made Chindy Dwiyanti Marheni Putri, ${ }^{1}$ Pudji Lestari, ${ }^{2}$ Muhammad Ilham Aldika Akbar ${ }^{3}$ \\ ${ }^{1}$ Faculty of Medicine Universitas Airlangga, Indonesia, ${ }^{2}$ Department of Public Health \\ Faculty of Medicine Universitas Airlangga, Indonesia, ${ }^{3}$ Department of Obstetrics and Gynecology \\ Faculty of Medicine Universitas Airlangga/Dr. Soetomo General Hospital Surabaya, Indonesia
}

\section{Abstract}

Background: The prevalence of human immunodeficiency virus (HIV) mother-to-child infection or vertical transmission of HIV, in Indonesia is about 90\%. Ministry of Health of the Republic of Indonesia Regulation No. 21 of 2013 stated that HIV infection in sexual productive age needs integrative professional help to lower the transmissions, including voluntary counseling and testing for pregnant women as well as all people at risk. This study aimed to determine the readiness of health workers to provide pregnancy planning program service for women with HIV.

Methods: This study was a descriptive study involving 30 obstetricians and 30 residents of Obstetrics and Gynecology specialist education in Surabaya, Indonesia. The respondents' knowledge on pregnancy planning for HIV-infected women based on based on guidance released by the Ministry of Health of Indonesia in 2017 and Regulation of Ministry of Health no. 52 the year 2017, as well as their attitude and readiness to provide pregnancy planning services, was explored. Questionnaires were distributed from August to December 2019 and the data collected were analyzed using Statistical Package for the Social Science (SPSS) version 17.0 and results were described in percentage.

Results: Most health workers (80\%) had good knowledge on providing pregnancy planning program for HIV positive women; however, only $63.3 \%$ had good attitude towards it. The majority of respondents $(90 \%)$ were ready to help HIV patients in planning their pregnancy.

Conclusions: Health workers in Surabaya are ready to provide services related to pregnancy planning for women infected with HIV.

Keywords: Human immunodeficiency virus, HIV transmission, pregnancy, readiness

\section{Introduction}

The Ministry of Health Republic of Indonesia has stated that the Human Immunodeficiency Virus (HIV) epidemic in the world has made it a problem that goes global. Within the scope of the Asian Continent, the fastest spread of this disease happens in Indonesia. The ranking of people living with HIV in East Java is currently the second-highest in Indonesia and the highest prevalence is in reproductive age. Therefore, the high number of HIV in reproductive women has a bigger chance of the increased number of HIV in pregnancy. In fact, the prevalence of vertical transmission in
Indonesia is approximately more than $90 \% .^{1-2}$ Not only making a bad impact on the mother, namely the higher pregnancy, labor, and puerperium risk, HIV transmission also will affect the baby growth and development. ${ }^{3}$

Proper pregnancy planning is needed, in hope; it will decrease the risk of transmission from mother to child. Based on the regulation of Ministry of Health no. 21 the year 2013, health professionals are needed to help to handle HIV transmission from mother to child. ${ }^{4}$ The Ministry of Health in 2015 issued a guideline that strongly demands the competence of doctors in pregnancy planning, including the knowledge that doctors must know and be able

Correspondence: Made Chindy Dwiyanti Marheni Putri, Faculty of Medicine, Universitas Airlangga, Jalan Mayjen Prof. Dr. Moestopo No.47, Surabaya, Indonesia, Email: made.chindy.dwiyanti-2017@fk.unair.ac.id 
to educate pregnancy requirements on people living with HIV/AIDS (PLWHA). For instance, the CD4 levels, viral load, and the use of contraception in PLWHA. Doctors must possess a good attitude toward PLWHA patients. Attitude concerning the absence of stigma and discrimination is needed to support the course of pregnancy planning. ${ }^{5}$ This research must be carried out because most studies about this field only focusing on the impact of patients but not the doctors' readiness. By knowing the doctors' readiness, it is expected that it can be a tool by doctors to evaluate themselves and give information to people, the hope they will know how our doctors are and may make good decisions whenever they want to consult the doctors. Therefore, it can help to make a better service and a better relation between doctors

Table 1 Knowledge of Obstetricians and the Residents towards Readiness in Pregnancy Planning for HIV-Infected Women

\begin{tabular}{|c|c|c|}
\hline \multirow{2}{*}{ Knowledge } & \multicolumn{2}{|c|}{ Correct answer } \\
\hline & $\mathbf{n}$ & $\%$ \\
\hline $\begin{array}{l}\text { Early detection of the risk of HIV infection, syphilis, and hepatitis B is } \\
\text { done through blood tests at least one time during pregnancy }\end{array}$ & 30 & 100 \\
\hline $\begin{array}{l}\text { Term of eligibility for pregnancy is healthy in general that is examined } \\
\text { by anamnesis and physical examination while laboratory verification is } \\
\text { not needed }\end{array}$ & 26 & 86.7 \\
\hline To diagnose HIV, we need to test the CD4 and viral load & 25 & 83.3 \\
\hline $\begin{array}{l}\text { Term of eligibility for pregnancy on PLWHA is already consumed ARV in } \\
6 \text { months, healthy in general, and declared fit to be pregnant by a doctor }\end{array}$ & 22 & 73.3 \\
\hline Suppressed viral load is a term of eligibility for pregnancy & 26 & 86.7 \\
\hline PLWHA who infected by TB is still allowed to be pregnant & 24 & 80 \\
\hline $\begin{array}{l}\text { HIV, Syphilis, and Hepatitis B early detection is held by the rapid } \\
\text { diagnostic test }\end{array}$ & 29 & 96.7 \\
\hline One of the risks of unplanned pregnancy is having a low birth baby & 27 & 90 \\
\hline $\begin{array}{l}\text { HIV, Syphilis, and Hepatitis B early detection in pregnancy may be } \\
\text { repeated by the couple minimum in the next } 3 \text { months or ahead of } \\
\text { pregnancy, or if the indication is founded }\end{array}$ & 23 & 76.7 \\
\hline Babies should not receive breast milk from HIV-infected mothers & 15 & 50 \\
\hline PLWHA are allowed to do a vaginal delivery & 26 & 86.7 \\
\hline $\begin{array}{l}\text { HIV detection is done with PCR DNA qualitative examination using } \\
\text { blood and dried blood spot on 6-weeks(or more) baby }\end{array}$ & 26 & 86.7 \\
\hline $\begin{array}{l}\text { One condition that will produce a healthy pregnancy in PLWHA couple } \\
\text { is having } 1 \text { or } 2 \text { HIV stage }\end{array}$ & 20 & 66.7 \\
\hline $\begin{array}{l}\text { PLWHA should consume ARV in a lifetime to reduce transmission risk to } \\
\text { the baby }\end{array}$ & 27 & 90 \\
\hline $\begin{array}{l}\text { PLWHA are allowed to have more than one child if already followed the } \\
\text { pregnancy planning program correctly }\end{array}$ & 21 & 70 \\
\hline PLWHA that are infected by malaria are eligible to be pregnant & 19 & 63.3 \\
\hline $\begin{array}{l}100 \% \text { of the baby from HIV mother should get ARV and cotrimoxazole } \\
\text { prophylaxis }\end{array}$ & 21 & 70 \\
\hline $\begin{array}{l}\text { Unplanned pregnancy risk for mother could be in the form of anemia } \\
\text { and infection }\end{array}$ & 26 & 86.7 \\
\hline Using condom as a contraception is enough for PLWHA couple & 20 & 66.7 \\
\hline PLWHA have to stop consuming ARV 6 weeks after the childbirth & 27 & 90 \\
\hline
\end{tabular}


and patients so that it can help to overcome a very crucial problem in this country, namely HIV. This research aimed to determine the readiness of health workers in pregnancy planning programs for women with HIV

\section{Methods}

This research was a descriptive observational study, conducted from August to December 2019 after obtaining approval from the Research Ethics Committee of Universitas Airlangga Hospital no. 167/KEP/2019. The sampling was performed using random sampling techniques, with sampling frames obtained from a member list of Perkumpulan Obstetri dan Ginekologi Indonesia (POGI) Surabaya and IDI Surabaya, including the obstetricians and the residents of the Obstetrics and Gynecology Department who were actively working on the implementation of pregnancy services at public and private hospitals Surabaya. The sample was calculated using the Z1- $\alpha / 22 p(1-p)$ :d2 formula with 0.1 limit error and 0.07 in a previously expected proportion, resulting in a minimum sample of 25 respondents.

A self-made questionnaire was distributed,

Table 2 Attitude of Obstetricians and the Residents towards Readiness in Pregnancy Planning for HIV-Infected Women

\begin{tabular}{|c|c|c|c|}
\hline \multirow{2}{*}{ Attitude } & \multicolumn{3}{|c|}{ Frequency } \\
\hline & Agree & Doubtful & Disagree \\
\hline $\begin{array}{l}\text { I will not use handschoen if I do the Leopold test on a mother } \\
\text { that is known to have HIV }\end{array}$ & 9 & 3 & 18 \\
\hline $\begin{array}{l}\text { In my opinion, women who are infected with HIV will } \\
\text { greatly affect the baby they are carrying, so they must be } \\
\text { immediately treated }\end{array}$ & 30 & 0 & 0 \\
\hline $\begin{array}{l}\text { I do believe with the existence of pregnancy planning } \\
\text { program on PLWHA will decrease the number of a baby born } \\
\text { with HIV }\end{array}$ & 27 & 1 & 2 \\
\hline $\begin{array}{l}\text { If there is HIV-infected woman come to my private practice, I } \\
\text { will still give her ARV }\end{array}$ & 24 & 2 & 4 \\
\hline As a doctor, I am aware of the chance to be infected by HIV & 30 & 0 & 0 \\
\hline $\begin{array}{l}\text { When giving counseling to pregnant women with HIV status } \\
\text { that is known to be positive, I consider there is no need to } \\
\text { use protective barriers }\end{array}$ & 15 & 1 & 14 \\
\hline $\begin{array}{l}\text { Pregnancy planning program on PLWHA must be } \\
\text { implemented }\end{array}$ & 28 & 0 & 2 \\
\hline $\begin{array}{l}\text { I am not afraid to make contact or provide services to } \\
\text { PLWHA even though there is the possibility of contracting it }\end{array}$ & 24 & 2 & 3 \\
\hline $\begin{array}{l}\text { I do not hesitate to use a thing that is already touched by an } \\
\text { HIV patient }\end{array}$ & 16 & 5 & 9 \\
\hline $\begin{array}{l}\text { I am ready to give counseling to HIV patient for a long } \\
\text { duration if needed }\end{array}$ & 29 & 1 & 0 \\
\hline $\begin{array}{l}\text { I will decide the eligibility of pregnancy for PLWHA if they } \\
\text { have already done the test related to HIV stage, CD4, viral } \\
\text { load, and the other infections }\end{array}$ & 26 & 2 & 2 \\
\hline $\begin{array}{l}\text { I will allow PLWHA that want to be pregnant and do vaginal } \\
\text { delivery with terms }\end{array}$ & 7 & 11 & 12 \\
\hline $\begin{array}{l}\text { In my opinion, PLWHA are allowed to deliver more than } 1 \\
\text { children }\end{array}$ & 16 & 7 & 7 \\
\hline $\begin{array}{l}\text { In my opinion, PLWHA are allowed to breastfeed the baby } \\
\text { with terms }\end{array}$ & 12 & 3 & 15 \\
\hline
\end{tabular}


Table 3 Category of Knowledge and Attitude of Obstetricians and the Residents towards Readiness in Pregnancy Planning for HIV Infected Women

\begin{tabular}{lcccc}
\hline \multirow{2}{*}{ Value } & \multicolumn{2}{c}{ Knowledge } & \multicolumn{3}{c}{ Attitude } \\
\cline { 2 - 5 } & $\mathbf{n}$ & $\mathbf{0}$ & $\mathbf{n}$ & $\mathbf{\%}$ \\
\hline Poor & 1 & 3 & 1 & 3.4 \\
Fair & 5 & 17 & 10 & 33.3 \\
Good & 24 & 80 & 19 & 63.3 \\
\hline
\end{tabular}

based on guidance released by the Ministry of Health of Indonesia in 2017 and Regulation of Ministry of Health no. 52 the year 2017 to assess knowledge, attitude, and readiness of doctors towards pregnancy planning program. The validity and reliability test were conducted by testing the questions to other 25 doctors not including in this research criteria, resulting in 20 questions for knowledge and 14 questions for the attitude. The knowledge was answered with correct or incorrect, whereas the attitude with agree, disagree, or doubtful. After a brief explanation of the purpose of this study, the informed consent form was signed before answering the questions. The result was classified as ready and not ready. Ready was designated if the respondent had good knowledge and attitude, or good knowledge with fair attitude, or fair knowledge with a good attitude. Not ready was designated if the respondents had poor knowledge and attitude, or fair knowledge and attitude. The answer above $75 \%$ was scored as good knowledge and good attitude; the correct answers 50-74\% were scored as fair and below $50 \%$ as poor. Data were analyzed using SPSS statistics 17.0.

\section{Results}

In total, 30 respondents were included consisting of $13(43 \%)$ residents and 17 (47\%) obstetricians of whom most of them $(70 \%)$ worked in public hospitals, male (63\%), and aged over 40 years old (48\%). The questionnaire and its result about knowledge and attitude were shown in Table 1 and Table 2 , respectively.

The majority of the respondents' knowledge about HIV / AIDS and pregnancy was good (80\%), whereas the attitudes were good in $63.3 \%$ as shown in Table 3.

The readiness of the physician showed that $46.67 \% \quad(n=14)$ respondents had good knowledge and attitude, 26.67\% (n=8) had good knowledge and fair attitude, and $16.67 \%$ $(n=5)$ had fair knowledge and a good attitude, resulting in a total of $90 \%$ readiness of the physicians towards pregnancy planning for HIV-infected women.

\section{Discussions}

Pregnancy planning is a program implemented by doctors to realize a healthy pregnancy, good parturition, and healthy baby. It is interesting to note that there are some of the characteristics that give no impact on the result, namely age and knowledge. Other studies supporting our result on factors related to the level of knowledge of health professionals, as well as on the relation of education level, age, and years of service to oral and dental health knowledge. $^{6-7}$ Specialists have more extensive experiences in the field of handling pregnant women compared to doctors trainee who are still in the education since experiences influence the knowledge. ${ }^{8}$

In order to lower the risk of transmission, the Indonesian government has targeted pregnant woman to be tested for HIV.6 Question no. 1 regarding early detection of HIV has been answered correctly in 100\%, and this proves that respondents already have knowledge of what should be done to eliminate HIV transmission from mother to child by government regulations.

There are many advantages for babies who receive breast milk from their mothers to fulfill nutrients, to protect babies from infections, to give a good impact on long-term health, and to reduce the risk of obesity and allergies. However, breastfeeding by mothers with HIV can increase the risk of transmission. Without HIV treatment, the risk of transmission is ranging from $5-20 \%$. To reduce this risk, the mother must continue taking ARVs, and their infants should also be given prophylaxis. The breastfeeding and replacement of breast milk should not be given simultaneously because it will cause injury to the baby's intestines and can increase the risk of HIV transmission to infants. $^{3}$ 
Half of respondents agree that it is a dilemma for doctors whether to prohibit or allow breastfeeding in HIV. Breastfeeding has a beneficial effect but also has a high risk for HIV transmission to the baby. To answer the dilemma, WHO has researched from 2011 to 2014 in various countries, including South Africa, Malawi, Tanzania, Uganda, Zambia, Zimbabwe, and India. In brief, 2431 pairs of mothers with HIV and their babies have been included, resulting in that almost $99 \%$ of these babies can live and reach their first birthday. In developing countries where adequate coverage of breast milk substitution is still challenging to obtain, the choice to breastfeed by HIV-positive mothers is a very safe choice for their babies. ${ }^{9}$

The effect that will arise in infants conceived by HIV-infected women is when a baby is born, and the risk of transmission is very high. Infants who are infected with HIV will experience a disruption in their growth and development. In the first few months, the mortality risk remains high if they are not given any treatments..$^{10}$ The risk of transmission from mothers with HIV if left untreated is $15-45 \%$. However, given appropriate interventions during pregnancy, childbirth, and breastfeeding, the risk can be reduced to below $2 \% \cdot{ }^{11}$ Interventions that can be performed by obstetricians when faced with women with HIV who are pregnant are by providing universal counseling, HIV monitoring, prophylactic administration of ARVs, and knowing the indications of assisting with proper cesarean delivery. ${ }^{12}$

All respondents agreed to the statement "In my opinion, women who are infected with HIV will greatly affect the baby they are carrying, so they must be immediately treated", concluding that all respondents had the right attitude when confronted with HIV women who were pregnant, namely providing immediate treatment in the hope of helping to reduce the risk that the baby could suffer. Handling is based on a good understanding of the prevention of motherto-child transmission (PMTCT). Medical staffs, especially obstetricians, need to understand and implement PMTCT well. ${ }^{13}$

Standard precaution is an effort to minimize the transmission of infectious diseases to health workers and it is recommended to avoid direct or indirect contact with blood, body fluids, and skin that is not intact. ${ }^{14}$ Protective barriers are not needed in conducting counseling activities. A balanced response between agreeing and disagreeing as well as hesitancy also shows that there is still uncertainty in the use of protective barriers. This finding suggests that doctors' understanding of HIV transmission still needs to be improved.

There is one respondent who scores low on knowledge and attitude. The factors that can influence the process of data retrieval including the psychological state of the respondent at the time the data was collected. When answering the questionnaire, the researcher observed that the respondent seemed to be in a hurry, and it was proven that the time in answering questions was less than 20 minutes. The state of mind at that particular time is very influential on how a person makes decisions, one of which is when answering statements in the questionnaire. ${ }^{15}$

This study certainly has limitations that the data is only given by respondents while the researchers did not directly observe when respondents were dealing with HIV patients.

To conclude, doctors are ready to plan the pregnancy on a woman with HIV. This readiness of obstetricians will give benefits to make the best action to reduce the mother to child HIV transmission. Therefore, the mother has the right prevention and treatment regarding to HIV and pregnancy.

\section{Acknowledgements}

We would like to thank the doctors in Dr. Soetomo Hospital, Airlangga University Hospital, Siloam Hospital, Husada Utama Hospital who participated in this study.

\section{References}

1. Lie $H$, Marianto M. Infeksi human immunofediciency virus (HIV) dalam kehamilan. CDK-276. 2019; 46(5):346-51

2. Tumangke H, Tappy M, Kendek R. Faktorfaktor yang mempengaruhi efektivitas pencegahan penularan HIV dari ibu ke anak (PPIA) di Kota Jayapura. Unnes Journal of Public Health. 2017; 6(4):261-5

3. Kementerian Kesehatan Republik Indonesia. Lembar balik perencanaan kehamilan bagi pasangan orang dengan HIV AIDS (ODHA) Jakarta: Kementerian Kesehatan RI; 2017 [cited 2 July 2020]. Available from: https://kesga. kemkes.go.id/assets/file/pedoman/ Lembar\%20Balik\%20Perencanaan $\% 20$ Kehamilan\%20Bagi\%20Pasangan $\% 20$ ODHA.pdf

4. Mujiati M, Lestary H, Sugiharti S. Kecukupan tenaga kesehatan dan permasalahannya dalam pelayanan kesehatan anak dengan 
HIV-AIDS di rumah sakit pada sepuluh kabupaten/kota, Indonesia. Media Litbangkes. 2017;27(1):1-8

5. Kementerian Kesehatan Republik Indonesia. Pedoman pelaksanaan pencegahan penularan HIV dan Sifilis dari ibu ke anak. Jakarta: Kementerian Kesehatan RI; 2015 [cited 2 July 2020] Available from: https://siha.kemkes. go.id/portal/files_upload/Pedoman_ Manajemen_PPIApdf.pdf

6. Wardani NII, Rejeki DSS, Masfiah S. Faktorfaktor yang berhubungan dengan tingkat pengetahuan kader kesehatan tentang thalassemia di Kecamatan Sumbang Kabupaten Banyumas. Kesmasindo. 2014;6(3):194-206

7. Dharmawati IGAA, Wirata IN. Hubungan tingkat pendidikan, umur, dan masa kerja dengan tingkat pengetahuan kesehatan gigi dan mulut pada guru Penjaskes SD di Kecamatan Tampak Siring Gianyar. Jurnal Kesehatan Gigi. 2016; 4(1):1-5

8. Cahyaningrum E, Siwi AS. Faktor-Faktor yang berhubungan dengan tingkat pengetahuan ibu dalam penanganan demam pada anak di Puskesmas I Kembaran Kabupaten Banyumas. Bidan Prada: Jurnal Publikasi Kebidanan. 2018;9(2):1-13

9. Flynn PM, Taha TE, Cababasay M, Fowler MG, Mofenson LM, Owor M, et al. Prevention of HIV-1 transmission through breastfeeding: efficacy and safety of maternal antiretroviral therapy versus infant nevirapine prophylaxis for duration of breastfeeding in HIV-1-infected women with high CD4 cell count (IMPAACT PROMISE): a randomized, open-label, clinical trial. J Acquir Immune Defic Syndr. 2018; 77(4): 383-92

10. Davies MA, Gibb D, Turkova A. Survival of HIV-1 vertically infected children. Curr Opin HIV AIDS. 2016; 11(5):455-64

11. Barral MFM, de Oliveira GR, Lobato RC, Mendza-Sassi RA, Martínez AMB, Gonçalves CV. Risk factor of HIV-1 vertical transmission (VT) and the influence of antiretroviral therapy (ART) in pregnancy outcome. Rev Inst Med Trop Sao Paulo. 2014; 56(2):133-8

12. Hardy E, Co-Uvin S. Care of the HIV-infected pregnant woman in the developed world. Obstet Med. 2015;8(1):13-7

13. Erliana N, Suryoputro A, Mustofa SB. Gambaran pelaksanaan prevention mother to child transmission di RSUD Kelas B Dr. R. Sosodoro Djatikoesoemo Kabupaten Bojonegoro. Jurnal Promosi Kesehatan Indonesia. 2016;11(2):1-17

14. Masyhuri I, Utari TR, Kusbaryanto K. Implementation standard precaution of risky dental treatments on patient with HIV-AIDS in $\mathrm{x}$ public health center Yogyakarta. Jurnal Medicoeticolegal dan Manajemen Rumah Sakit. 2019;8(2):7789

15. Johanes J, Daya T. Peran faktor psikologis terhadap keputusan investasi produk mulia pada PT. Pegadaian (Persero) Di Kota Jambi. Digest Marketing. 2017;2(1):21021. 